\title{
When the City is Your Classroom
}

\author{
Milla Cozart Riggio \\ Trinity College (CT)
}

Lisa G. Sapolis

Trinity College (CT)

\section{Xiangming Chen}

Trinity College (CT)

Students who attend Trinity College in Hartford, Connecticut, have elected to spend their university years in one of America's most distinguished small cosmopolitan cities. The site of the Hartford Convention of 1814-1815, the home of America's oldest continually operated art museum (The Wadsworth Atheneum) and longest continually published newspaper (The Hartford Courant), and the historical residence of Mark Twain and Harriet Beecher Stowe: the Hartford that was once known for its New England character is now densely multi-ethnic. One of the proportionately largest West Indian communities in the U.S., as well as significant Puerto Rican, Peruvian, Portuguese, Brazilian, Nigerian and other African populations cohabit with many others in the Greater Hartford urban area that has an overall population of just over one million people $(1,059,878 ; 2000$ census), centered in a city of roughly 125,000 (124,397 in 2008, http:// www.idcide.com/citydata/ct/hartford.htm) ${ }^{1}$

Though not a large city, Hartford's transformation reflects the process of globalization characteristic of post-industrial cities worldwide, which makes the city itself an important learning arena for American students, both at home and abroad. ${ }^{2}$ Over the last two decades as the world has become rapidly urbanized, with half the planet's population living in cities by 2008 , the city, especially in developing countries, has become a critically contested site where economic poverty, environmental degradation, residential segregation, and the search for identity in the face of fluid migratory patterns pose serious challenges and provide unprecedented learning opportunities. Moreover, students studying and living in cities almost anywhere in 
the world learn how urbanization - by creating problems and challenges that cross national, international, and disciplinary boundaries - has begun to collapse the distinctions between the so-called First and Third worlds. Connecting their learning experiences overseas with those at home, students are better positioned to comprehend the complex world around them. The urban and global initiative at Trinity College provides fresh examples for rethinking the changing relationship between study abroad and the city.

\section{The Trinity College Model}

As one of the few small liberal arts colleges located in a city, we at Trinity had a choice to make: either enclose our students on a small isolated campus, or embrace the city as a place where students can both live and learn. Choosing the latter, we have developed a simple educational creed: Life and learning are not inseparable. The "real world" is not something you brace yourself to enter at the end of your education. That world is with you - politically, economically, socially, culturally - even as you prepare to take the responsibility for running it. There is much talk of the need to educate students to become citizens of the world. Capitalizing on our location, Trinity College gives meaning to this clichéd rhetorical notion. We train our students for a world that is complex, multi-ethnic, globalized, and cross-culturally connected in a way that no previous society could have imagined.

Far removed from the romance of the city reflected by writers like Lewis Mumford (The City in History, 1961), the past few decades have shown us not only the impact of globalization on cities themselves, but also the resilient capabilities of cities to recover from the devastating urban blight that seemed initially to threaten their existence (See, for instance, Jacobs, 1993). Over this same period, the character of the city and the challenges it poses have changed. The globalized contemporary city, which in the terms of Anthony Orum and Xiangming Chen "is no longer local," is as paradoxical as it is complex, its social structures as dependent on the contested appropriation of public spaces as on any rational planning process (Orum and Chen, 2003, p. 55; see also Lefebre, 1992, and Harvey, 2009). Migratory populations still compete with each other to control urban spaces, even as local neighborhoods continue to fight city hall for limited resources. Meanwhile, multinational corporations have been globalizing, leveling, and aggressively marketing once resistant and subversive popular cultures — joining with 
other economic and political forces in dissolving, redrawing, but also paradoxically entrenching the boundaries between nations and even within them among different ethnicities, religions, and tribes.

One reaction to modern migratory patterns is the merging, intermixing, and re-making of cultural identity — what we may call identity reformation; the other is to assert more powerfully, especially in the face of modernizing technologies, a fundamental, resistant concept of identity - exemplified by tribal allegiances, religious fundamentalism, and other manifestations of traditional cultures. ${ }^{3}$ Arguably not since the early developmental period of European imperial colonialism has the concept of "us" and "them" been so sharply drawn - a line etched in the sand by both fear and blood. The transforming power of the cyber revolution has produced an urbanized world that is simultaneously fragmented and integrated (see Orum and Chen, 2003, p. 120), where, ironically, one can now live in Mumbai, India, and work in the "virtual workplace" of Dallas, New York, or London (Abrahamson, 2004, p. 19). And yet, to wear a turban in Washington, D.C. is to invite intrusive governmental scrutiny.

How students comprehend and experience this radically changing world will determine much about the future of all of us. At Trinity, our Center for Urban and Global Studies recognizes that "students today should be encouraged to go beyond the traditional classroom learning and connect their knowledge to real-life world problems and solutions" (Anselmi, 2008, $\mathrm{np}$ ). We have, in the terms of our strategic curricular review, "identified the urban, the global, and a paradigm of teaching and learning as distinguishing features of Trinity's conception of liberal arts with a difference" (www.trincoll.edu/pub/resources/Ghome.htm, 1997, np; italics added).

We conceptualize the learning experience in terms of a set of concentric circles, beginning with the small inner circle of the campus, expanding to the broader surround of Hartford, and, building on the local foundation, extending the final circle to both study away and abroad. Moving students from the inner circle of the campus to the local city, Trinity programs engage students persistently in the City of Hartford, not as patrons but as partners. ${ }^{4}$ Through Trinity's Community Learning Initiative (CLI), our students both study and experience "Hispanic Hartford." Biology students work with the Park River Development project to help measure pollutants in and recover the river known to locals as Hog River. Arts, humanities, and social science students join their scientific 
fellows working, studying, and doing internships throughout the City of Hartford. Under the directorship of one of our co-authors, the A.V. Davis Summer Institute of Urban and Global Studies offered twenty fellowships a year for two years $(2007,2008)$ to students who worked, lived, and undertook independent research projects in the City of Hartford. Taking the global as well as the urban option, Davis Fellows carried their research to such countries as Venezuela, Cambodia, and Sao Tome and Principe.

Expanding into the outer academic circle, Trinity has developed a campus in Rome, five Global Learning Sites in strategic cities around the globe, including Cape Town, South Africa; Vienna, Austria; Paris, France; Barcelona, Spain; and Port-of-Spain, Trinidad, as well as an "Urban Arts" program at LaMaMa Theater in New York, on all of which students study for a semester or a year. In addition, Trinity is developing a new program in Buenos Aires, Argentina, and offers short-term study programs, primarily in the summer, in places such as China, Cambodia, and Italy. ${ }^{5}$ In this article, we will use as examples two of Trinity's many approaches to study abroad that illustrate our presumption that the city is your classroom: the Trinity-in-Trinidad Global Learning Site and Trinity's faculty-led summer program "Connections: Boomtowns of the Yangtze River" in four emerging megacities in China.

Though students who spend a full semester or even an academic year in Trinidad don't have in their minds that they are going to study the city or its urban environment, because of the immersive nature of the program, they end up having as much of an urban experience as those who self-consciously theorize the city. Students in the summer "Connections" program more directly study issues related to urbanization - economic development, migration and community, environmental issues. Both programs share Trinity's sense that the urban must be linked to the global, as well as our basic commitment to the idea that learning does not, indeed cannot, stop at the classroom door.

\section{Trinity-in-Trinidad G Iobal Learning Site: The City as Your CIassroom}

In a seminal article in Frontiers, Anthony Ogden uses the metaphor of colonial cultures to describe expectations that U.S. students have about study abroad: 
Education abroad has not been immune to the pervasive consumerism mentality seen in U.S. higher education... Not surprisingly, a distinct type of education abroad student appears to be emerging... the colonial student... who really wants to be abroad and take full advantage of all the benefits studying abroad offers, but is not necessarily open to experiencing the less desirable side of being there... Like children of the empire, colonial students have a sense of entitlement, as if the world is theirs for the discovery, if not the taking. New cultures are experienced in just the same way as new commodities are coveted, purchased, and owned. (Ogden, 2008, pp. 37-38)

Ogden's solution is to lure students "off the veranda" from which the "colonial student does his/her experiencing” (Ogden, p. 39). In Trinidad, a complex post-colonial culture with a working infrastructure not dependent on tourism offers the opportunity, literally, to move students from the "venerable veranda" into a transformative immersion experience that motivates them to "step outside their comfort zones" (Ogden, p. 39). By working with local institutions ranging from the city or national government to Human Rights NGOs, television stations and newspapers, health providers, and many others, students experience for themselves the diversity of ways in which urban institutions that have evolved from a colonial origin interact with each other, as well as analyzing how the work of individuals - directors, scholars, social activists — can impact urban social structures, services, and opportunities.

The Trinity-in-Trinidad Global Learning Site immerses students in an island nation that is simultaneously pre- and post-industrial. ${ }^{6}$ First a Spanish and then a British colony, with a majority French Creole presence among the plantation owners, Trinidad is an oil and gas producing island, which now supplies almost $80 \%$ of the liquefied natural gas used throughout the United States (Romero, 2004, p. B1). ${ }^{7}$ This small nation is the world's largest exporter of both methanol and ammonia. ${ }^{8}$ At the same time, this Caribbean island moves to the rhythms of its many ethnic and religious groups, which celebrate each other's festivals and holidays even as they struggle competitively for positions of power and authority in the culture itself.

The concepts of "east" and "west" have been intertwined ever since Christopher Columbus first decided to sail west to reach the east. In Trinidad, just a few miles off the coast of Venezuela, they literally meet. Indo-Trinidadians 
constitute the largest single population at roughly $40 \%$ of the million and a half inhabitants, with those who claim Africa as their ancestral homeland close behind (approx. 37.5\%), and a wide range of ethnicities merging and intermingling in one of the most diverse cultures in the world (2000 census; see http:// www.indexmundi.com/trinidad_and_tobago/demographics_profile.html).

Based in the greater Port-of-Spain city area, which is roughly comparable to though slightly smaller than Hartford in size and ethnic density, the program offers students unique opportunities, to live with, study, and experience cultures they will not find elsewhere, such as an English-speaking Muslim culture with a strong female presence. ${ }^{10}$ How urban space is deployed is central conceptually to the program, which begins with an art and architecture tour of Port-of-Spain led by internationally acclaimed artist Chris Cozier and architect Sean Leonard. They ask students to use the architectural patterns of the city and its suburbs as a key to understanding not only the history of this particular island, but also the larger issues affecting urban evolution.

For instance, two sections of land reclaimed from the sea flank Port-ofSpain to the east and west, parallel in every way except that one is wealthy and the other very poor: the appropriately named West Moorings is structured around expensive, gated communities for the affluent; while in a parallel position to the east, Sea Lots houses squatters who build their homes from makeshift materials, siphon their electricity from other sources, and deal daily with the impact of poverty on their lives. Experiencing this and other historically determined distinctions and meeting people in areas of the city they could never enter alone, students are forced to confront in human terms issues of poverty, environmental degradation, social stratification and its consequences, and the structural implications of zoning laws. Thus embodied, urban theory comes to life to a degree that classroom discussions alone cannot replicate.

Similarly, another class taught by the core course coordinator Sunity Maharaj Best focuses on a day of food preparation that both teaches students how to shop inexpensively at local markets and engages them intellectually in the link between food and cultural history (How can you possibly feed 17 people with one chicken? And why would anyone try?). Throughout the term, two core courses - "Caribbean Civilization" and "Festival Arts as Cultural Performance" - provide the theoretical underpinning that informs 
the reality of their active Trinidad lives. ${ }^{11}$ Each student has an independently developed internship that provides a uniquely personal entré to the society as a whole: one student helped to draft UN resolutions; another student, studying on the program from the University of Colorado, started a foundation to support students working at the Margot Kistow Home for Children. ${ }^{12}$

The success of this approach to international, urban study is reflected in the fact that more than $80 \%$ of the students return to Trinidad and Tobago for a second semester, or on their own, to continue studies begun at the site or to pursue connections they have made through the program. For a surprising number, Trinidad has become a second home. Whatever their focus, students inevitably come to understand the way in which economics, politics, environmental issues, ethnic tensions and resolutions, and a wide range of cultural issues merge to sustain the ongoing life of the city, which in its turn, is key to the island and the Republic.

In the decade that the Trinidad Global Learning Site has been in existence, the courses have been tailored for close to two hundred students, $40 \%$ of whom are students of color, with no two programs exactly alike. With specially designed tracks that include documenting Trinidad (through video and still photography); music; gender and Islamic Studies; Hindu Trinidad; ecology and environmental studies; theater and dance; Caribbean Studies; human rights; and engineering (in development), the basic program offers many options, all of them linking the capital city to the life of the island, and each coordinated by a Trinity professor with a particular interest in the subject matter of the track. The internships directly engage the students in the local community, many working with NGOs that serve children, women, or provide legal services.

These tracks mix and mingle to maximize the individual experience, so that, for instance, a biology and religion major can study both on the Hindu Trinidad track and work in the rain forest with a shaman and healer who is also a forest ranger. (This student Kristin Liska '10 is now in 2009-2010 doing her senior thesis on the secular/religious intersections in Transcendental meditation). ${ }^{13}$ Professor Joan Morrison of the Trinity biology department, who coordinates the environmental track and also participated in the first summer China "Connections" program, says that students can study rain forests the world over; what distinguishes the Trinidad site is its focus not only on biology, but also on the way the forest functions in the life of the island, linking its rural and urban areas. 
Two case studies, chosen from dozens, reflect the diverse ways in which students can engage and learn directly from the city itself: one at the outset of our program eleven years ago and one recent, both leading to career choices, though in different directions. The first case study is the story of an English major, now a filmmaker and urban specialist. Stephen McFarland '00 was on Trinity's first semester program in Trinidad in the spring of 1999. Soon after arrival, Steve picked up his first video camera, the Canon G2 that had been purchased for the site, and for the next five months, it might as well have been glued to his back, so carefully did he guard it and so continuously did he use it. With an internship at Banyan Productions, he learned the skills and ethics of documentary filmmaking. ${ }^{14} \mathrm{He}$ became the videographer not only for the site itself, but for other projects, archiving and preserving local stories for posterity. Returning home, Steve took his interest both in filmmaking and in urban archival work to new places:

The Trinidad trip affected me deeply. Our travels and encounters in all areas of Port of Spain, from the shantytowns of Sea Lots to the colonial mansions of St. Clair opened my eyes to the city and gave me a rich comparative perspective from which to understand cities back home. In carnival season and after, I saw many examples of the ways in which public spaces, identities, and culture are mutually constitutive of each other. My internship in video with Banyan Productions gave me skills that would come in handy the next year back at Trinity, when I got involved with the Hartford Studies Project, which was then undertaking a documentary film project that looked at Hartford's history since the riots of the 1960s through archival footage and interviews with Hartford residents and activists. ${ }^{15}$ My involvement in that project culminated (so far!) in 2005 with a permanent video installation on urban renewal in Hartford at the Connecticut Historical Society, which I wrote and coedited. In the meantime, I completed a Master's program in City and Regional Planning at Cornell, where my studies focused on community and economic development, and where my capstone project drew on my work with the HSP to examine the use of film and video as a tool of public participation in local planning processes. In the Fall of 2008, I entered into the doctoral program in Geography at CUNY Graduate Center, where I am studying with David Harvey, Neil Smith, and other eminent urbanists. I am now developing an idea for a dissertation on 
"Spaces of Labor" - union halls and worker centers - in US cities since the turn of the last century (McFarland 2009).

Steve's story is not unique. Another student, Maggie Griffith 02, who went to Trinidad planning to follow her father's career as a lawyer, was one of several who returned as filmmakers. Maggie, who completed her honors religion thesis in Trinidad, comparing Hindu festivals of Phagwa in Trinidad and India, has done a Master's degree in "Broadcasting, Telecommunications, and Mass Media" at Temple University and is close to defending her Ph.D. project in communications at the University of Illinois at Chicago. ${ }^{16}$ In Trinidad, she made a film that was aired on national television, on a musical form called Pichakaaree, invented by her mentor and local thesis director Raviji, who directs our Hindu Trinidad track, for the spring festival of Phagwa that Maggie was studying. ${ }^{17}$ In a world in which religious difference often drives violence, the ability to de-mystify the cultural other, to make the apparently exotic familiar by both studying and living with Hindus, Muslims, African Orishas, Shouter Baptists, or others in their own habitat is, without doubt, a potent life lesson. ${ }^{18}$

In addition to making films, students frequently produce exhibits of photographs or paintings, under the guidance of Trinity photographer and Professor of Fine arts Pablo Delano and one of several distinguished Trinidad artists and photographers (including Jeffrey Chock, Chris Cozier and others). Beyond the visual arts, music students also engage the life of the city, through the music that is imbedded in the overall ethos of this island. Generated by the late ethnomusicologist Trinity Professor Lise Waxer and now coordinated by her successor Professor Eric Galm, the music track provides - among other options - opportunities to play with major steel orchestras, and to study the history of steel drums, also known as pan, claimed as the only acoustic instrument invented in the twentieth century, turning industrial waste (abandoned oil drums) into orchestral instruments. Students once again link their study and their experience to the paradox of the island: the persistent interactivity between the urban nature of the place, its industrial, oil and gas centered economic base, and its festival cultures.

However, Trinity-in-Trinidad is by no means a site for artistic students alone. Student who have enrolee include engineering and economics majors, 
marine biologists, history, psychology, philosophy, religion, and human rights students, not only from Trinity but also from other colleges and universities. One of our major concentrations is on Human Rights. The second case study is that of Bethany Riley '10, a Human Rights major, who spent the academic year 2008-2009 on the Trinity-in-Trinidad program. In the summer of 2009, as one of only two undergraduate students (and the youngest) among hundreds of scholars, artists, and graduate students, she participated in an international Encuentro (seminar) of the prestigious Hemispheric Institute of Performance and Politics in Bogotá Colombia. Beth presented on the effects worldwide of mentoring inner city youths, comparing Boston, Hartford, and Port-of-Spain to other cities around the world.

An athlete as well as a student who has triumphed over a basic learning disability, Beth began her urban studies in her home city of Boston, where during the summers she was a columnist for Commonwealth, MassInc's quarterly publication (see Riley 2008). In Hartford, Beth continued her primary research on mentoring groups, while also analyzing school programs and serving as a classroom aide in a local fifth grade classroom.

In the ever-expanding circle that moves from the local to the global, Beth continued her primary research while spending a year in Trinidad. There, she was a teaching assistant in the Arima Boys Roman Catholic School, where she frequently found herself teaching alone. For a group known as Credo House, she "conducted street walks with Alwin the program coordinator, where we checked with people in the areas about any youth that may have been spotted continuously out of school and in the same clothes. Also learned how to spot pickpockets to try to locate males in the capital city who could be homeless. Inside the program, I tutored, mentored and evaluated male youth. The end resulted in me writing a social and psycho analysis of 2 boys that I worked with all semester" (Riley 2009).

In addition, Beth worked with mentor Cristo Adonis, a healer and forest ranger from the Carib community in Arima, to plan activities during "indigenous week," while giving tours of the Carib center to primary school kids and documenting public hearings and events for this community. In Portof-Spain, she worked with Senator Dana Seetahal, helping to edit briefs and do research for criminal court cases, which she attended in both high and superior courts. She also did academic research comparing the British and U.S. legal systems. 
With this background, Beth is in the spring of 2010 completing her Human Rights senior thesis; she has applied for a Fulbright Fellowship to continue her Trinidad research. This scholar athlete from Boston now projects a career helping to create one or more mentoring institutions in the Caribbean. From Boston to Hartford to Port-of-Spain (and even Bogotá, Colombia), this student - exemplary of many others who have followed similar trajectories - has taken her interest both in Human Rights and in the life of the inner city beyond any reach she could have imagined without the interlinkage between her home city, her campus and its city environs, and study abroad, one circle broadening into the next, until they embrace an entire life.

\section{Connections: From Hartford to the Yangtze River Megacities}

Just as the Trinidad program has forged a strong connection between the Trinity campus, Hartford, and a rich international urban experience, Trinity's new summer program in China is intended to achieve a similar goal, albeit through a different structure and alternative approach. In 2009, Trinity College launched a summer program in both Hartford and China, "Connections: Boomtowns of the Yangtze River," which took 21 students and three faculty members through four of China's megacities along the Yangtze River after a one-week immersion on campus and in the city of Hartford. Sponsored by the Center for Urban and Global Studies (CUGS) with support from the China Urban Studies Summer Endowment Fund and the O’Neill Asia Cum Laude Endowment, the program consists of three linked and complementary traveling courses taught by three faculty members in the disciplines of sociology, history, and environmental science: a sociology course, "Megacities of the Yangtze: Challenges and Opportunities," taught by Dr. Xiangming Chen, Dean and Director, Center for Urban and Global Studies and Raether Distinguished Professor of Sociology; a history course, "River Cities of China: The History of Urban Culture Along the Yangtze," taught by Associate Professor of History, Michael Lestz; and an environmental studies course, "Environmental Challenges Posed by Urban Life Along the Yangtze," taught by Professor of Biology, Joan Morrison. Taking a multidisciplinary approach to the study of cities locally and globally, the China program breaks new ground in study abroad for Trinity College by 
integrating the humanistic, social scientific, and physical scientific perspectives on pressing urban issues in the US and Chinese contexts. We present below how this innovative study-abroad program has advanced students' intellectual and experiential understanding of the city in three distinctive and interdependent ways.

\section{The City in Change and Continuity}

With historian Michael Lestz taking the lead, the program used the industrial and social history of Hartford and the Connecticut River to introduce the more recent rapid transformation of the Yangtze River cities. Reading about Hartford's industrialization and urbanization, taking a Connecticut River cruise, and visiting the Connecticut River Museum in Essex, the students learned, surprisingly to most, that Hartford was once a regional and national industrial powerhouse that produced guns (the Colt revolver), ammunition, typewriters (the Underwood brand), and bicycles. ${ }^{19}$

Beginning in the 1960s, Hartford-based manufacturing declined and then disappeared, as companies and factories moved to the American South and overseas. While Hartford remains a major insurance center, the city has become economically depressed, largely due to deindustrialization. The population has declined from a peak of around 160,000 in the 1960s to about 125,000 today, with a transition to a racially and ethnically diverse city of African-Americans, Puerto Ricans, and other more recent immigrants from the Caribbean (see the Trinidad program), South America, and Eastern Europe. ${ }^{20}$

The students' urban history lesson continued in China on our first stop in the city of Chongqing, a sprawling city-region located at the upper reaches of the Yangtze River. Despite the vast difference in urban scale, what the students learned in Hartford facilitated their understanding of Chongqing. As the largest river port and regional center for southwestern China, the early commercial and trading importance of Chongqing goes back hundreds of years. More recently, the city was the political capital of the Nationalist Regime during the Japanese War from 1937 to 1945, a period with strong connections to the United States through the influence of General Stillwell, who advised the Nationalist government at the time. More recently, the dizzying pace of Chongqing's recent industrial boom has turned the city into China's largest motorcycle manufacturing center with exports to Asia and beyond. The new "North Zone" of Chongqing was converted in five years 
from a mountainous area into a metropolis of modern office buildings and factories. Currently, the area boasts Fortune 500 names like Microsoft, HP, and Ford. The urban core of Chongqing (defined as the area within one hour's radius of the city center) is exploding demographically and projected to expand the population from about 7 million people today to approximately 22 million by $2020 .{ }^{21}$ Given this projection, we asked the students to consider what might happen to Chongqing if rapid industrialization and urbanization continue at their current pace. How, we asked, might the implications of the stages and timing of Hartford's industrial history pertain to the trajectories of Chongqing's dramatic industrial and urban expansion?

The theme of urban change and continuity took us from Chongqing to Wuhan, Nanjing, and Shanghai down the Yangtze River. The city of Wuhan, which is located in the middle of the Yangtze, is known as "the Chicago of China," for its massive heavy industries. In spite of this, Wuhan is taking aggressively forward-looking measures to reduce its polluting industries and develop new "green" alternative energy sources and high-tech ventures around its numerous Yangtze River-linked lakes. Having learned about Wuhan's industrial history and the polluting effect of Chongqing's rapid industrial growth, some students expressed skepticism about whether the city's ambitious master plan could actually be implemented. The ancient, culturally rich, but heavily industrialized city of Nanjing provided the students with a good example of balance between change and continuity or deconstruction (tearing down and building up) and preservation.

When the program reached its final destination of Shanghai at the mouth of the Yangtze River, the students were greeted with a more advanced picture of rapid economic transformations in this historic and most western and cosmopolitan Chinese city. Shanghai is rising as the "New York of China," with the country's largest concentration of financial and trade service functions. The service sector alone accounts for over 50 percent of the city's GDP, far exceeding that of the other three cities (Chen, ed., 2009). The students had a close-up view of the new Shanghai's massive skyline in Pudong, erected over the last decade or so; they also explored the "old" Shanghai, including the disappearing, old-style local houses in narrow alley lanes.

Starting with Hartford and ending with Shanghai, the "Connections" program offered students a valuable history lesson: once a city takes root and begins to travel along a specific path of development, it is difficult for 
it to change course. Why? In part, because cities develop their own specific histories and narratives about themselves, tales that help constitute the city, how it grew, and its unique and defining characteristics (Orum and Chen, 2009, 237-249). The differences in scale aside, the history lesson of a city's directional path rings true in both the US and Chinese urban contexts. This historical perspective enabled the students to investigate contemporary change and its social consequences in the city.

\section{The City as a Lived Community}

Through the urban sociology course taught by Dean Xiangming Chen, the Connections program oriented the students to look beyond the developmental stages of the city to understand it as a social community where real people live. Again, the city of Hartford provided the point of departure and reference for our sociological inquiry into the residential structures and lived experience of Chinese city dwellers. A basic understanding of Hartford's history allowed the students to see sustained unemployment, poverty, and depressed neighborhoods as the socioeconomic consequences of deindustrialization. In addition, we guided the students to understand the lasting impact of a fragmented localregional governance structure on Hartford, such as the city-suburban and public-private divides in educational achievement, especially between whites and African-Americans or Latinos. The students learned that the absence of county government (eliminated in the 1960s) exacerbates inter-local competition for resources, ${ }^{22}$ leaving Hartford hemmed in by a largely prosperous metropolitan region without any effective region-wide governance.

Once the program moved to Chongqing, the challenge was to visualize the sociological structure of the local communities in this very different setting. Drawing on his extensive research on Chinese cities, Dean Chen briefed the students on two basic social and political conditions that exist in this and other megacities. The first is the massive number of rural migrants who work on busy construction sites, hawk their wares on crowded streets, and live in substandard housing. The second is the presence of a strong municipal government that attempts to manage, under the city's administration, this influx of migrants from the rural and semi-urban hinterlands. The students quickly observed the socio-spatial disparity between the living quarters of many poor migrants and the new luxury apartment buildings and gated villas inhabited by the local rich. This observation was given 
further sociological meaning when the Chair of Urban Planning at Chongqing University asked the students to ponder how the local community was changing as a result of large-scale urban renewal and rural in-migration, with increasing numbers of local residents living in high-rise apartment towers. Although the students didn't see the kind of racial and ethnic diversities and disparities that exist in Hartford, their interaction with local Chinese professors prompted them to think about the new differentiation of local communities in megacities like Chongqing and Shanghai. ${ }^{23}$

From Chongqing, the students and faculty took a three-day Yangtze River cruise through the Three Gorges to Yichang, near Wuhan, to study the gigantic Sandouping Dam, the world's largest and most expensive engineering project. The dam is altering the Yangtze River-long known as China's main corridor of transport and commerce-by generating new hydrolytic power, stopping chronic flooding, and extending large-ship transport upstream to Chongqing. In addition to prompting the students to think about the economic and infrastructure implications of the dam, the cruise gave the students a moving opportunity to broaden their understanding of the dam's impact on the people living along the river banks. The most tragic is the displacement of approximately 1.5 million local residents in small towns and villages along the river; these will be submerged underwater once the dam is completed in 2010. At one stop, the students received firsthand information on the scale of local rural residents who had been displaced en masse. After hearing that about 120,000 residents had been relocated from an old town to a new community at a farther point on the other side of the river, Trinity student Ezra Moser'10 was quick to equate the number to Hartford's current population, ${ }^{24}$ making a nice connection between these two cities.

\section{The City as an Ecological System}

The environmental science course taught by Professor Morrison (former director of the Environmental Science program at Trinity) provided a third lens through which the students could investigate the varied environmental aspects of urbanization. Anchored to the comparative premise that Hartford and the Chinese megacities are all river cities, the course focused largely on the Connecticut and Yangtze Rivers. The students read a number of articles on ecology and sustainability ${ }^{25}$ and attended lectures by Professor Morrison to prepare them for their investigations in China. They went on 
a Connecticut River cruise guided by Professor Morrison, and discovered that in the1930s, the river was polluted by raw sewage and dumping that occurred along much of the waterway's 400-mile course, from Quebec to the Long Island Sound. A visit to the Hartford water treatment facility and garbage museum, respectively, provided related and additional insights into the interdependent relationship between industrialization, urban growth, and environmental pollution and protection in the past and present of the Greater Hartford region in relation to the Connecticut River. In short, the faculty used Hartford and the Connecticut River to show how a river could be reclaimed and to illustrate some important concepts and points of reference for the examination of the larger river cities in China.

Having breathed the clean air in Hartford and seen the clear (cleanedup) water in the Connecticut River, the students were struck by the severe pollution in the Chinese cities, where the air is thick and smoggy and the Yangtze River is muddy-colored and littered with trash. We met with a rare local environmental NGO in Chongqing that both works with and against the municipal government in advocating for and educating on environmental protection. The head of the NGO passionately described the severity of environmental degradation with an alarming reference to over one billion tons of industrial and municipal wastewater being dumped into the Yangtze River. This explained the color and appearance of the water. ${ }^{26}$ The talk demonstrated the critical importance of the many socially conscious college students in China in spreading the message of environmental preservation. This was reiterated through a subsequent meeting with an environmental group made up of college students in the city of Wuhan, where our students toured their "greening" project in a local public park. It was these intensive and engaged local programs that reinforced the students' understanding of the spatial scope of the environmental problem in Chinese cities and of the important, growing grass-roots response to it.

The environmental lessons struck another cord at the Three Gorges Dam at the end of the river cruise. Here Professor Morrison and a knowledgeable local tour guide explained the complex ecological impact of building a massive dam on the river's eco-system. The students learned about the gradual disappearance of the Yangtze River dolphins and the slow extinction of the river sturgeons, which can no longer swim upstream past the dam, in contrast to the return of fish to the much cleaner Connecticut River. 
In Shanghai, the students continued to learn about the environmental issues faced by cities. Here they experienced horrendous traffic jams and the accompanying pollution. The ever growing number of private cars in this booming megacity of almost 20 million people clogs the ever-expanding elevated highways that cannot keep pace with public demand for more cars. In addition, with over 4,000 buildings of 20 or more stories built in the last 15 years in Shanghai, most with inefficient individual window air-conditioners, heavy pressure has been placed upon the energy supply and added to $\mathrm{CO} 2$ emissions. China has just passed the United States as the world's largest CO2 emitter. ${ }^{27}$ Because cities consume two-thirds of the world's total energy use, the students learned valuable lessons from the Yangtze River megacities. With their huge demand and strain on all types of resources, they demonstrate how a city constitutes a fragile ecological system that must be cared for by all.

\section{Conclusion}

In distinctive and complementary ways, the Trinidad and China programs have illustrated how Trinity College through its urban and global educational mission is broadening and deepening the use of the city (in Hartford and globally) to better prepare our students for our urbanized and globalized world. While the Trinidad program exemplifies more of the study in the city, the China program places more emphasis on the study of the city. The Trinidad program is centered on urban culture, while the China program revolves around the triangle of urban history, urban sociology, and environmental science. Both programs link the academic domain with experiential learning, the China program more conventionally through courses that all the students take together, the Trinidad program with a combination of core courses and individually designed immersion projects. Several students who attended the Trinidad program have gone on to graduate studies in filmmaking, music, and city planning, while four of the students who participated in the inaugural launch of the China program in summer 2009 are in the process of starting and completing selfdesigned urban studies majors. One of them, Ezra Moser (mentioned in the China program section earlier) went through Trinity's gateway Cities program in his first year, participated in the China program, completed an urban internship with the Hartford Park River Watershed Initiative in fall 2009, applied for a Fulbright for India, and is planning to pursue a Master's 
program in urban and regional planning in the United Kingdom after graduation. The China program provided a key component of Ezra's cumulative growth in the urban field. ${ }^{28}$

As representatives of our academic term and summer study abroad initiatives, these two programs exemplify the Trinity mission of getting our students off the veranda: of giving them a real world education, while helping them to develop critical thinking and problem-solving skills. Our goal is to prepare them for their careers, future study, and their roles as global citizens by giving them critical urban and international experience while they are students. We do not aim to create a generation of expatriates. But recognizing that, indeed, the city is "no longer local," we believe that urban, global experience is the best way to help students better understand what is going on in their own country. Experiencing Hartford and studying abroad coalesce to give students insights into their own home cities, whether these are in the United States or elsewhere. We take them abroad not to give them a romantic student overseas junket, but to teach them about themselves in the context of the world in which they must live, over which they must be trained to take control.

\section{References}

Abrahamson, M. (2004). Global Cities. Oxford and New York: Oxford University Press. Urban and Global Studies at Trinity College.

Anselmi, D. (2008). Where the urban meets the global age. In X.Chen (Ed.), Brochure of the Center for Urban and Global Studies at Trinity College. Castells, M. (1983). The City and the Grassroots. Berkeley: University of California Press.

Chen, X. (2007). "A tale of two regions in China: rapid economic development and slow industrial upgrading in the Pearl River and the Yangtze River Deltas." International Journal of Comparative Sociology, 48 (2-3), 167-201.

Chen,X.,ed.(2009).Shanghai Rising:StatePowerandLocal Transformations in a Global Megacity. Minneapolis: University of Minnesota Press.

Close, S. (2001). "Fire in the bones: Hartford's NAACP, civil rights and militancy, 1943-1969," Journal of Negro History, 86 (3), 228-263.

Conart, R. (1964). Politics of Regional Planningin Greater Hartford, A research report published by the Greater Hartford Chamber of Commerce. 
"Connections: Boomtowns of the Yangtze River" (2009). An educational video produced by Bailey Pryor of Telemark Films, shot in June and completed in November.

Connerton, P. (1989). How Societies Remember. New York: Cambridge University Press.

Delano, P. Personal Interview. 15 October, 2009.

Fang, J. \& Kiang, C.S. (2006). "China’s environment: challenges and solutions." Frontiers in Ecology and the Environment, 4 (7), 339.

Friedman, T. (1999). The Lexus and the Olive Tree. New York: Farrar, Straus, and Giroux.

Griffith, M. (2002). "One festival, Two cultures: The Holi/Phagwa festival in India and Trinidad," Hartford, CT; Unpub. Trinity College undergraduate thesis.

Hall, P. (1984). The World Cities. 3rd edition. London: Weidenfield \& Nicolson.

Harvey, D. (2009). Social Justice and the City: Geographies of Justice and Social Transformation. Revised edition. Athens, Georgia: University of Georgia Press.

Harvey, D. (1991). The Condition of Postmodernity: An Enquiry into the Origins of Cultural Change. Reprint edition. Oxford: WileyBlackwell.

Hawley, A. (1950). Human Ecology: A Theory of Community Structure. 1st edition. New York: The Ronald Press Company.

Hovland, K. (2009). "Global learning: What is it? Who is responsible for it?” Peer Review, 11 (4), 4-7.

http://quickfacts.census.gov/qfd/states/09/09003.html. (2009). Hartford County QuickFacts from the U.S. Census Bureau. Last accessed December 29, 2009.

Jacobs, J. (1993). The Death and Life of Great American Cities. (1993). Modern Library Edition. New York: Random House.

Joerss, M., Woetzel, J. R., \& Zhang, H. (2009). “China's green opportunity," The McKinsey Quarterly, May.

LeFebre, H. (1992). The Production of Space. Oxford: Wiley-Blackwell.

MacFarland, S. Personal interview. 15 October, 2009.

Molotch, H. (1976). "The city as a growth machine." American Journal of Sociology, 82, 309-332. 
Mumford, L. (1961). The City in History: Its Origins, Its Transformations, and Its Prospects. New York: Harcourt Brace and World.

Ogden, A. (2008). "The view from the veranda." Frontiers: The Interdisciplinary Journal of Study Abroad, XV, 35-66.

Orum, A. \& Chen, X. (2003). The World of Cities: Places in Comparative and Historical Perspective. Oxford: Wiley-Blackwell.

Riggio, M. C. (1998). "Resistance and identity: Trinidad and Tobago Carnival." The Drama Review, Special issue on Trinidad and Tobago Carnival, guest edited by M. C. Riggio, 7-23.

Riggio, M. C. (2004). "Time out or time in? The urban dialectic of carnival," in M.C Riggio, ed., Carnival: Culture in Action - the Trinidad Experience, London and New York: Routledge, pp. 13-30.

Riley, B. Personal email. 15 November, 2009.

Riley, B. (2008). "Mentor program brings college option to low income youths." CommonWealth Magazine, Fall 2008: 15-16.

Romero, S. (2004) “Trinidad becomes a Natural Gas Giant". The New York Times, 13 October 2004: web: www.nytimes.com/2004/10/13/ business/worldbusiness/13gas.html. Last accessed December 31, 2009. Sassen, S. (2001). The Global City: New York, London, Tokyo. 2nd edition. Princeton: Princeton University Press.

Warner, W. (1947). The Social Life of a Modern Community. New Haven: Yale University Press.

Williams, E. (1963). History of the People of Trinidad and Tobago. Reprint. Brooklyn A \& B Book Publishers.

www.ageinamerica.org/Hartford.html. (2009). Age in America: Section on

Hartford, Connecticut. Last accessed December 29, 2009. www.city-data.com/us-cities/The-Northeast/Hartford-Economy.html.

(2006). City-Data.com section on the Hartford Economy. Last accessed December 29, 2009.

www.citypopulation.de/Trinidad.html.(2007). City Population of Trinidad. Last accessed December 29, 2009.

www.epa.gov/NE/eco/uep/hartford/index.html. (2007). Urban Environmental Program in New England: City Program Overview for Hartford, Connecticut. Last accessed December 29, 2009. 
www.icis.com/v2/chemicals/9075154/ammonia/uses.html. "Ammonia

Uses and Market Data,"(2009). ICIS.com Newsletter. Last accessed 01 January, 2010.

www.idcide.com/citydata/ct/hartford.htm. (2009). Profile of Hartford,

Connecticut. Last accessed December 29, 2009.

www.indexmundi.com/trinidad_and_tobago/demographics_profile.html.

(2008) CIA World Fact Book: Trinidad and Tobago Demographics

Profile 2009. Last accessed 1, January 2010.

www.nationsencyclopedia.com/Americas/Trinidad-and-Tobago-

ENERGY-AND-POWER.html. "Energy and Power - Trinidad and

Tobago," (2010) Encyclopedia of the Nations: Americas: Trinidad and

Tobago. Last accessed 1 January, 2010.

www.trincoll.edu/pub/resources/Ghome.htm (1997). Trinity College

"Global Learning Sites Objectives" from old website on Global Learning

Sites. Last accessed December 29, 2009.

Zukin, S. (1996). The Culture of Cities. Oxford: Wiley-Blackwell.

\section{End not es}

1 "Although Connecticut has been stereotyped as a largely white and wealthy state, Hartford's demographics reflect a more diverse population. The city's ethnic composition differs greatly from the other Age in America sites with the population at $40.5 \%$ Hispanic, 38.1\% Black, and $17.8 \%$ White." (http://www.ageinamerica.org/Hartford.html). See also (http:// quickfacts.census.gov/qfd/states/09/09003.html

2 Contributing to the exemplary complexity of the Hartford region is the fact that the city, itself one of the poorest in the nation, is located in an affluent region (http://www.city-data.com/us-cities/The-Northeast/Hartford-Economy.html). See further discussion in the "Connections" section below.

3 See, for instance, Thomas Friedman's The Lexus and the Olive Tree (1999) for an analysis of this conflict between post-industrial modernity and tradition throughout the world.

4 The distinction between the patronage and partnership models of student interaction with the city are crucially important in establishing relationships of equality between town and gown. At Trinity one good model for partnership is Trinfo Café, directed by Carlos Espinosa, a Trinity graduate with a local Hispanic background. 
5 The LaMaMa program is coordinated through the Trinity College Department of Theater and Dance, and is run by Michael Burke. The summer Cambodia program - co-directed by Trinity Professors Michael Lestz and Pablo Delano (also a professional Puerto Rican photographer) - offers students the opportunity to link study in Hartford with historical, artistic, and sociological immersion in Cambodia. The summer program in Italy, codirected by Trinity economic Professors Diane Zannoni and Carol Clark, is centered on the city of Florence, where students link modern economics to Florentine history; these summer programs attract roughly 50 students per year; they are comparable in their range and achievements to the China "Connections" program that will be discussed in this article.

6 Trinidad with its 2,000 square miles is the larger of two islands in the Republic of Trinidad and Tobago.

7 The first working oil world in the world outside of Azerbaijan on the Caspian Sea was built in 1857 in the La Brea region of Trinidad.

8 "As of 2002 Trinidad and Tobago was the world's leading exporter of both methanol and ammonia." ("Energy and Power," 2010, np); see also "Ammonia Uses and Market Data" (2009, np).

9 Greater Hartford with its roughly 1 million people is somewhat larger than greater Port of Spain, which spans from Diego Martin in the west to Arima in the east, with roughly 600,000 of Trinidad's 1,337,684 million population (http://www.citypopulation.de/Trinidad.html). But Hartford with its roughly 125,000 people is comparable to the cosmopolitan population of Port of Spain. Both are relatively small capital cities, surrounded by expansive suburbs, some of which are significantly richer than the city itself. The demographics are comparable enough to encourage comparison. 10 The Islamic Academy in Maraval, Port of Spain, which provides both medical and educational facilities, was founded by a female physician, Dr. Joan Kazim. Our Islamic and gender studies track is coordinated by Professor Janet Bauer, who is doing important original research on the Muslim women of Trinidad.

11 "Caribbean Civilization" is coordinated by Sunity Maharaj Best of the Lloyd Best Foundation, named after the late Lloyd Best, himself a partner in our program, in collaboration with our two program administrators, Shamagne Bertrand and her sister Florence Blizzard. "Festival Arts as Cultural Performance" is taught by prizewinning Trinidad filmmaker and playwright Tony Hall, founder of the Lord Street Theater. Trinity Political Science Professor Brigitte 
Schulz, one of our affiliated faculty members, has sent students to work directly with the Lloyd Best Institute. One of them, Sarah Haddock '03, did her undergraduate honors thesis using materials she helped the Institute to archive and organize, with plans to pursue further graduate work.

12 Trinity internship coordinator Anne Lundberg has been an invaluable aid in implementing these internships.

13 Trinity College Religion professors Leslie Desmangles and Ellison Findly, working with the track facilitator Trinidad Hindu leader and community worker Raviji (Ravindra Nath Maharaj), are instrumental in making the Hindu track one of our most popular and successful study options.

${ }^{14}$ Banyan's co-founder Christopher Laird, who recently received an honorary doctoral degree from the University of the West Indies, has also established a television station known as Gayelle, whose purpose is to create local programming designed to focus on Trinidad culture. Tony Hall was one of the co-founders of Banyan, with which he still maintains ties.

15 The Trinity-based Hartford Studies project, directed by Professors Susan Pennybacker and Steve Valocchi, received a grant of $\$ 100,000$ from the Rockefeller Foundation to produce a full length film (currently on hold), utilizing valuable, unedited film footage from the 1960s found in the basement of Butch Lewis, a former leader of the Black Panther organization in Hartford.

${ }^{16}$ Maggie's dissertation, tentatively titled, "Taxis, Technology, and Transnationals: Communication practices of Chicago's transnational taxi drivers," further reflects her post-Trinidad focus on international, cross-cultural, urban issues.

${ }^{17}$ Maggie's undergraduate thesis "One festival, Two cultures: The Holi/ Phagwa festival in India and Trinidad," was jointly directed by Raviji and Trinity Professor Ellison Findly.

${ }^{18}$ We have compiled a valuable library of cultural archives, particularly documentary films. For more information, contact Professor Milla Riggio (milla. riggio@trincoll.edu).

${ }^{19}$ Pope Park near Trinity campus was named after the Pope family enterprise, which made an early model of bicycles around the turn of the 20th century and almost became a major car manufacturer.

${ }^{20}$ See Tuckel, Schlichting, and Maisel (2007), pp. 710-736; Close (2001), pp. 228-263.

${ }^{21}$ As the first field trip in each of the four Yangtze River cities, we visited the comprehensive municipal planning exhibition hall to set up the spatial context for local programming activities. In Chongqing, the students were 
struck by the great density of the projected population of 22 million within the stretched boundary of Chongqing's future urban core, which makes it the world's largest experiment with government-orchestrated local and regional urbanization through rural-urban migration.

${ }^{22}$ See Ralph W. Conart (1964), a research report published by the Greater Hartford Chamber of Commerce.

${ }^{23}$ See Lu, Ren, and Chen, pp. 191-213.

${ }^{24}$ Ezra Moser's comments appeared in an educational DVD on the China program, which can be obtained by connecting Dean Xiangming Chen at Trinity College (xiangming.chen@trincoll.edu).

${ }^{25}$ See Fang and Kiang (2006), p. 337.

${ }^{26}$ The talk by the head of the NGO in Chongqing was excerpted in the educational DVD on the China program.

${ }^{27}$ Joerss, Woetzel, and Zhang (2009).

${ }^{28}$ Another student Michael Magdelinskas '11, an English major, who also went through the Cities program in his freshmen year, attended the A.V. Davis Institute mentioned earlier, participated in the China program, studied at the Trinity-in-Paris Global Learning Site in spring 2010, and will complete a self-designed urban and global studies double major. 